\title{
CLONAL TYPES AND ANTIMICROBIAL RESISTANCE PROFILES OF METHICILLIN-RESISTANT Staphylococcus aureus ISOLATES FROM HOSPITALS IN SOUTH BRAZIL
}

\author{
Leandro Reus Rodrigues PEREZ(1,2) \& Pedro Alves D’AZEVEDO(1,3)
}

\begin{abstract}
SUMMARY
In the present study were evaluated the DNA macrorestriction profile and SCCmec types for nine multi-resistant MRSA selected. Also antimicrobial susceptibility testing by disk diffusion method was evaluated for 68 MRSA isolates against 12 antimicrobial agents. The isolates were recovered from blood culture collected from hospitalized patients in three hospitals of Porto Alegre, Brazil. PFGE and PCR for mecA and SCCmec I, II, III, IV types genes were done on selected nine isolates with susceptibility only to vancomycin, teicoplanin and linezolid. Two clone profiles, with five subtypes, were demonstrated among multi-resistant MRSA analyzed. Eight isolates showed harbor SCCmec type III and one isolate was not typeable. The knowledge of SCCmec type, clone and antimicrobial profiles among S. aureus is essential mainly to prevention and control of dissemination of the antimicrobial resistance.
\end{abstract}

KEYWORDS: Staphylococcus aureus; MRSA; SCCmec; Typing; Drug resistance

\section{INTRODUCTION}

Staphylococcus aureus is an important agent of nosocomial and community-acquired infections. The methicillin resistance characterization is crucial for therapeutic and epidemiologic surveillance programs ${ }^{11}$. Methicillin resistance is characterized through exogenous acquisition of a mobile genetic element called staphylococcal chromosomal cassette mec (SCCmec) $)^{4,5}$. In Brazilian hospitals, MRSA are responsible for about $37 \%$ of staphylococcal infections. A single MRSA clone, called Brazilian endemic clone MRSA, is responsible by great majority of infections ${ }^{8,14}$. However, studies have reported the occurrence of community-acquired MRSA (CA-MRSA) infections in south Brazil that equally to others CA-MRSA harboring the particular SCCmec type $\mathrm{IV}^{7,10}$.

In this study we investigated antimicrobial susceptibility and molecular (typing and SCCmec types) characteristics associated with MRSA infections in hospitalized patients of Porto Alegre City, south Brazil.

\section{MATERIAL AND METHODS}

Bacterial isolates: A total of 68 consecutive MRSA isolates were recovered from blood cultures of patients admitted in three hospitals (Hospital de Clínicas - HCPA, Irmandade Santa Casa de Misericórdia - ISCMPA and Grupo Hospitalar Conceição - GHC) located in Porto Alegre City. The isolates were collected from August/2004 to
December/2004. Only one isolate of each patient was included in the study. All samples were frozen and stored at $-20{ }^{\circ} \mathrm{C}$ in skim milk with $10 \%$ glycerol. All isolates were identified as $S$. aureus by Gram stain, tube coagulase production and mannitol fermentation. All were characterized as methicillin-resistant by polymerase chain reaction (PCR) for detection of the mecA gene, as previously described ${ }^{7}$.

Antimicrobial susceptibility testing: Antimicrobial susceptibility was evaluated by disk diffusion method according to Clinical Laboratory and Standards Institute 2006 (formerly NCCLS) recommendations ${ }^{3}$. The following antimicrobial agents and concentrations $(\mu \mathrm{g})$ (Becton Dickinson, Sparks, MD) were tested: vancomycin $(30 \mu \mathrm{g})$, teicoplanin $(30 \mu \mathrm{g})$, linezolid $(30 \mu \mathrm{g})$, gentamicin $(10 \mu \mathrm{g})$, erythromycin $(15 \mu \mathrm{g})$, clindamycin $(2 \mu \mathrm{g})$, ciprofloxacin $(5$ $\mu \mathrm{g})$, trimethoprim/sulfametoxazol $(23.75 / 1.25 \mu \mathrm{g})$, penicillin (10 $\mathrm{U})$, chloramphenicol $(30 \mu \mathrm{g})$, tetracycline $(30 \mu \mathrm{g})$, and rifampin $(5 \mu \mathrm{g})$.

Pulsed Field Gel Electrophoresis: Molecular typing was realized by pulsed field gel electrophoresis (PFGE) after SmaI digestion as previously described ${ }^{9}$. Banding profile was analyzed by visual inspection. Isolates were considered as different genotypes when presented more than six band differences ${ }^{12}$. The choice criterion for typing was susceptibility only to vancomycin, teicoplanin and linezolid.

SCCmec determination type: Characterization of SCCmec type was performed by PCR procedure, as described by OLIVEIRA \& DE 
LENCASTRE ${ }^{8}$. The choice criterion of MRSA isolates was the same adopted for PFGE submitting.

\section{RESULTS AND DISCUSSION}

Higher resistance rates (intermediate and full) were noted for gentamycin and erythromycin $94.11 \%$ (64/68) followed by clindamycin $91.17 \%$ (62/68), ciprofloxacin 89.7\% (61/68), trimethoprim/ sulfametoxazol $88.23 \%(60 / 68)$, penicillin $97.05 \%(66 / 68)$, chloramphenicol $47.05 \%(32 / 68)$, tetracycline $83.8 \%(57 / 68)$ and rifampin $76.47 \%(52 / 68)$. Nine isolates $(13.23 \%, 9 / 68)$ presented resistance to all antimicrobial agents except vancomycin, teicoplanin and linezolid.

The knowledge of the DNA macrorestriction profiles of MRSA is crucial to establish the prevalence of multiresistant isolates among the distinct medical centers also to control the dissemination horizontal of this resistance. Besides, the character "methicillin-susceptible" among staphylococci is easily transferable for "methicillin-resistant" due to an element genetic called SCCmec ${ }^{2}$. This element highly mobile is a 21-67 kb fragment of DNA that, for movement, carries two specific genes designated as cassette chromosome recombinase A and B (ccr A and $c c r \mathrm{~B}$ ), which encode recombinases of the invertase/resolvase family, with great capacity of dissemination ${ }^{13}$.

The SCCmec type III, also type II, confers characteristics of multiresistance to $\mathrm{MRSA}^{6}$. Differently, elements designated SCCmec type $\mathrm{IV}$, no harboring drug-resistance genes other than mecA, which was consistent with the most notable characteristic of CA-MRSA susceptibility to many non- $\beta$-lactam antimicrobials ${ }^{6}$. In report by RIBEIRO et al. ${ }^{10}$, CA-MRSA harbored SCCmec type IV was descript in Porto Alegre City.

Although usually community acquired, TRINDADE et al..$^{13}$ show the SCCmec type IV S. aureus occurrence as clearly nosocomial. For that reason, monitoring of dissemination of MRSA isolates is an element important for study of the epidemiologic scenario.

In this study, SCCmec typing revealed that eight MRSA isolates harbored SCCmec type III and one other isolate harbored a non-typeable SCCmec. This is in accordance with multi-resistant character among isolates analyzed.

Nine multi-resistant MRSA isolates were submitted to PFGE typing. The clone profiles are shown in the Fig. 1. PFGE profiles showed two distinct biotypes, termed $\mathrm{A}$ and $\mathrm{B}$, divided in five subtypes, A1, A2, A3, B1 and B2. The MRSA Brazilian clone (A1) was recovered in $2 / 3$ and $3 / 5$ of the isolates from HCPA and ISCMPA institutions, respectively. A clone " $\mathrm{B}$ " no-relatedness to the MRSA Brazilian clone was recovered from ISCMPA (subtype B2) and GHC (subtype B1) institutions. Clones relatedness to the MRSA Brazilian clone, A2 and A3 subtypes, were recovered from ISCMPA and HCPA institutions, respectively.

Out of nine DNA macrorestriction profiles obtained, four were clonally related and these isolates, strongly related with MRSA Brazilian clone, are from three distinct centers. Results from an international survey indicate that the Brazilian clone has a large capacity

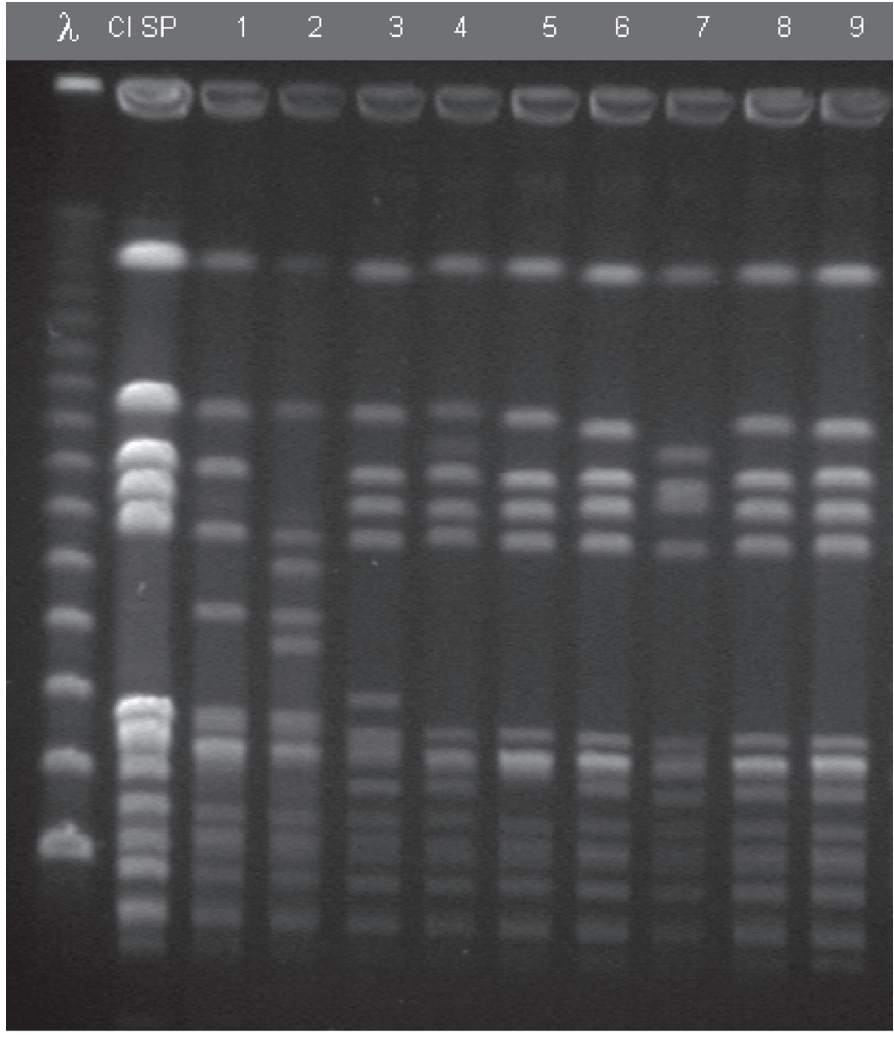

Fig. 1 - PFGE profiles of SmaI-digested genomic DNAs of MRSA isolates recovered from hospitalized patients in Porto Alegre City, Brazil. Lane $\lambda$, molecular weight marker (48.5 $\mathrm{kb}$ ); lane CISP, Brazilian endemic clone MRSA; line 1 MRSA isolate from Grupo Hospitalar Conceição; lanes 2-6, MRSA from Irmandade Santa Casa de Misericórdia (ISCMPA) and lanes 7-9, MRSA isolates from Hospital de Clínicas (HCPA).

for geographic expansion and persistence ${ }^{9}$. However, a clone norelatedness to the MRSA Brazilian clone was recovered in 2/4 institutions, GHC and ISCMPA (clones B1 and B2 subtypes, respectively). Thus, we think that these findings could be illustrating the presence of other clonal types among MRSA isolates in our hospitals. Studies with more samples are necessary to establish a clonal tendency among MRSA isolates causing nosocomial-acquired infections.

The same isolates submitted to the PFGE were examined for characterization of SCCmec type. SCCmec type III was detected in eighgt MRSA isolates. The SCCmec type characterization was not possible for one MRSA. All MRSA isolates included for SCCmec typing that presented SCCmec type III were resistant to sulfamethoxazoletrimethoprim, showing that this is not a characteristic of multi-resistant Brazilian endemic clone ${ }^{1}$. This showed that a unique phenotypic profile is poorly sufficient for a clonal characterization.

In conclusion, we have demonstrated that genetic determinant of the methicillin resistance (mecA gene) among multi-resistant MRSA isolates from hospitals of Porto Alegre City, south Brazil, is carried by SCCmec type III. In spite of the low number of isolates analyzed, there was a variation in DNA macrorestriction profiles of MRSA, with 

trop. S. Paulo, 50(3): 135-137, 2008.

the presence of two types, A and B. The knowledge of the occurrence of SCCmec types as well as clonal and phenotypic profiles determination among $S$. aureus and other staphylococcal species are essentially helpful to prevent the spread of these agents and to supervise the resistance in the local scenario.

\section{RESUMO}

Tipos de clones e perfis de resistência antimicrobiana de Staphylococcus aureus resistentes à meticilina isolados de hospitais no sul do Brasil

No presente estudo foram avaliados o perfil de macrorrestrição do DNA e tipos de SCCmec para nove MRSA multirresistentes selecionados. Além disso, susceptibilidade a 12 agentes antimicrobianos pelo teste de disco-difusão foi avaliada para 68 isolados de MRSA. Os isolados foram obtidos de hemoculturas de pacientes hospitalizados de três hospitais de Porto Alegre, Brasil. PFGE e PCR para detecção do gene mecA e para os tipos genéticos SCCmec I, II, III e IV foram realizados em nove isolados selecionados que apresentaram susceptibilidade somente a vancomicina, teicoplanina e linezolida. Dois perfis clonais, com cinco subtipos, foram demonstrados entre os isolados analisados. Oito isolados apresentaram SCCmec tipo III e um isolado não foi caracterizado quanto ao tipo de SCCmec. O conhecimento do tipo de SCCmec bem como dos perfis clonais e de susceptibilidade aos antimicrobianos entre isolados de $S$. aureus é essencial, principalmente, para a prevenção e controle da disseminação da resistência antimicrobiana.

\section{ACKNOWLEDGEMENTS}

The authors are grateful to CAPES, CNPq and Fundação Faculdade Federal de Ciências Médicas de Porto Alegre (FFFCMPA).

\section{REFERENCES}

1. AMORIM, M.L.; AIRES DE SOUSA, M.; SANCHES, I.S. et al. - Clonal and antibiotic resistance profiles of methicillin-resistant Staphylococcus aureus (MRSA) from a Portuguese hospital over time. Microb. Drug resist., 4: 301-309, 2002.

2. CHONGTRAKOOL, P.; ITO, T.; MA, X.X. et al. - Staphylococcal cassette chromosome mec (SCCmec) typing of methicillin-resistant Staphylococcus aureus strains isolated in 11 Asian countries: a proposal for a new nomenclature for SCCmec elements. Antimicrob. Agents Chemother., 50: 1001-1012, 2006.
3. CLINICAL AND LABORATORY STANDARD INSTITUTE - Performance standards for antimicrobial susceptibility testing. Wayne, CLSI, 2006. (Document M100S15).

4. KATAYAMA, Y.; ITO, T. \& HIRAMATSU, K. - A new class of genetic element, staphylococcus cassette chromosome mec, encodes methicillin resistance in Staphylococcus aureus. Antimicrob. Agents Chemother., 44: 1549-1555, 2000.

5. KURODA, M.; OHTA, T.; UCHIYAMA, I. et al. - Whole genome sequencing of meticillinresistant Staphylococcus aureus. Lancet., 357: 1225-1240, 2001.

6. OKUMA, K.; IWAKAWA, K.; TURNIDGE, J.D. et al. - Dissemination of new methicillinresistant Staphylococcus aureus clones in the community. J. clin. Microbiol., 40 4289-4294, 2002

7. OLIVEIRA, D.C.; TOMASZ, A. \& DE LENCASTRE, H. - The evolution of pandemic clones of methicillin-resistant Staphylococcus aureus: identification of two ancestral genetic backgrounds and the associated mec elements. Microb. Drug resist., 7: 349 $361,2001$.

8. OLIVEIRA, D.C. \& DE LENCASTRE, H. - Multiplex PCR strategy for rapid identification of structural types and variants of the mec element in methicillin-resistant Staphylococcus aureus. Antimicrob. Agents Chemother., 46: 2155-2161, 2002.

9. OLIVEIRA, G.A.; FARIA, J.B.; LEVY, C.E. \& MAMIZUKA, E.M. - Characterization of the Brazilian endemic clone of methicillin-resistant Staphylococcus aureus (MRSA) from hospitals throughout Brazil. Braz. J. infect. Dis., 5: 163-170, 2001

10. RIBEIRO, A.; DIAS, C.; SILVA-CARVALHO, M.C. et al. - First report of infection with community-acquired methicillin-resistant Staphylococcus aureus in South America J. clin. Microbiol., 43: 1985-1988, 2005.

11. ROBINSON, D.A. \& ENRIGHT, M.C. - Evolutionary models of the emergence of methicillin-resistant Staphylococcus aureus. Antimicrob. Agents Chemother., 47 3926-3934, 2003

12. TENOVER, F.C.; ARBEIT, R.D.; GOERING, R.V. et al. - Interpreting chromosomal DNA restriction patterns produced by pulsed-field gel electrophoresis: criteria for bacterial strain typing. J. clin. Microbiol., 33: 2233-2239, 1995.

13. TRINDADE, P.A.; PACHECO, R.L.; COSTA, S.F. et al. - Prevalence of SCCmec type IV in nosocomial bloodstream isolates of methicillin-resistant Staphylococcus aureus J. clin. Microbiol., 43: 3435-3437, 2005.

14. VIVONI, A.M.; DIEP, B.A.; MAGALHÃES, A.C. et al. - Clonal composition of Staphylococcus aureus isolates at a Brazilian University Hospital: identification of international circulating lineages. J. clin. Microbiol., 44: 1686-1691, 2006.

Received: 31 May 2007

Accepted: 1 April 2008 